\title{
ПРАВОВЕ ЗАБЕЗПЕЧЕННЯ НЕДОТОРКАНОСТІ ПРЕЗИДЕНТА ТА НАРОДНИХ ДЕПУТАТІВ УКРАЇНИ
}

\author{
РУСЕЦЬКИЙ Анатолій Анатолійович - доктор юридичних наук, доцент, \\ заслужений юрист України, головний науковий співробітник Харківського \\ науково-дослідного інституту судових експертиз ім. Засл. проф. М. С. Бокаріуса \\ https://orcid.org/0000-0003-2234-4392 \\ DOI:10.32782/LAW.2020.1.1 \\ УДК: 342.95 (477)
}

Розглянуті питання правового забезпечення недоторканості Президента та народних депутатів України. За допомогою аналізу наукових поглядів сбормовано та надано авторське визначення понять «недоторканість» та «правове забезпечення» (по відношенню до правового статусу спеціальних суб'єктів). Визначено характерні особливості діяльності таких суб’єктів та їх правового статусу як передумов забезпечення їх недоторканості. Надано пропозицй стосовно вдосконалення інституту недоторканості Президента та народних депутатів України. Запропоновано зміни та доповнення до национального законодавства щодо підвищення ефбективності діяльності народних обраниів та вдосконалення мотивувально-заохочуваних форм їх професійної діяльності.

Ключові слова: недоторканість, правове забезпечення, юридична рівність, спеціальний статус, державна влада, правове регулювання, законодавство, гілка влади, реборми.

Постановка проблеми

Починаючи 3 незапам'ятних часів icторії людства, кожна правляча верхівка у будь-якій державі воліла на власний розсуд встановити такі правила, які 6 закріплювали іï панівне положення у суспільстві, а також створити та зафіксувати певні бар'єри, якими вона хотіла відгородитися від інших верств населення.

Існує безліч конкретних історичних прикладів подібної діяльності представників державної влади. Серед одних з найпер- ших та достовірно відомих із них є багатостолітня діяльність давньоримської аристократії. Нащадки тих трьохсот осіб, якими була заснована Римська держава, узурпували для себе усі тогочасні політичні права, у тому числі було наголошено, що лише так звані «нобілі» мають виключне право займати ключові державні посади, такі як посада консула, проконсула, сенатора, цензора та чимало інших.

Через призму багатотисячної історії розвитку суспільних та соціальних відносин по всьому світу традиція наділяти керівництво політичної влади певними привілеями, яких не існує у більшості звичайних громадян, а також традиція закриватися від своїх виборців різноманітними фізичними, економічними та юридичними бар'єрами продовжують так чи інакше існувати. Звичайно, що подібна «практика» не обійшла стороною Україну, де здавна існували засилля та безкарність можновладців. Проте, у зв'язку зі зміною політичної ситуації, відбувається зникнення владних привілеїв.

Аналіз останніх досліджень і публікацій

Різноманітні питання, що стосуються правового забезпечення недоторканості Президента та народних депутатів України та його специфічних рис, були предметом дослідження багатьох науковців. Безпосередньо питання розгляду, вивчення та систематизації понятійних категорій у сфері привілеїв та особливих прав, якими наділя- 


\section{Теорія, історія держави і права, конституційне право}

лися певні представники політичного керівництва держави, здійснення ними своїх фахових функцій, сучасне місце таких привілеїв серед вітчизняних адміністративно-правових норм, а також сучасна проблематика їх характерних особливостей та їх порівняння з соціально-політичними ситуаціями в інших країнах досліджувались у наукових працях: М. М. Воронова, Н. Г. Григорук, В. С. Журавського, В. М. Кампо, О. В. Майданника, О. О. Майданник, О. В. Петришина, В. Ф. Погорілка, М. Ф. Селівона, С. Г. Серьогіної, О. Ф. Скакун, Ю. М. Тодики, О. Ф. Фрицького, В. М. Шаповала та інших фахівців.

Метою даної статті є дослідження специфіки та характерних особливостей адміністративно-правових засад функціонування певних суспільно-політичних привілеїв для представників державного керівництва в Україні, а також пошук відповіді на питання щодо необхідності збереження подібних архаїчних привілеїв чи їх спростування.

Також до мети написання цієї статті входить доведення, шляхом наукового опрацювання, вагомого впливу якісного функціонування політичної системи, зокрема, іiї законодавчої гілки, на увесь процес перетворення вітчизняного державного механізму на більш потужний і якісний.

\section{Виклад основного матеріалу}

Для того, аби більш ретельно та повноцінно розглянути специфіку та проблематику питання недоторканності певних, чітко визначених законодавством осіб, слід зазначити, що особливості цієї тематики, а також наукові погляди на неї є різними. Адже інститут недоторканості має місце не лише в тих державах, де існують авторитарні режими, головною метою яких $\boldsymbol{\epsilon}$ лише узурпація влади та власне збагачення. Подібні звичаї надання недоторканості представникам вищого політичного інстемблішменту також історично функціонують і в країнах із сталими правовими та демократичними порядками і традиціями. Необхідно наголосити на тому, що у таких країнах ця практика залишається через те, що виступає гарантом захищеності осіб, що мають тимчасову недоторканність від їх неправомірного кримінального переслідування під час виконання ними професійних обов'язків.

Проте, слід зазначити, що в Україні, якщо порівнювати іï політичну систему 3 розвиненими країнами Західного світу, недоторканність політиків найвищого рівня має непомірно широкий характер, що значною мірою ускладнюе розслідування здійснених ними злочинів та правопорушень. Можна навіть констатувати, що донедавна норми чинного кримінального процесуального законодавства України майже повністю унеможливлювали здійснення швидкого, повного та неупередженого розслідування і притягнення до кримінальної відповідальності осіб, які зловживали власною недоторканністю.

У вітчизняних науковців нема сумніву у тому, що однією з найбільш невідкладних справ повинна стати робота з удосконалення правового регулювання розслідування злочинів, які були вчинені особами, що користувалися своєю недоторканністю у злочинних цілях. Спеціалістами зазначається, що конкретними шляхами перетворення їх науково-теоретичних поглядів у реальні дії мали б стати модифікація існуючих або ж створення принципово нових форм і методів проведення розслідувань, а також пропонування дієвих ініціатив з перегляду усталеної практики проведення окремих процесуальних дій [1].

Надані вище твердження потребують бути доповненими тезою про те, що проведення будь-яких слідчих чи оперативно-розшукових дій по відношенню до осіб iз недоторканністю або ж притягнення їх до кримінальної відповідальності повинні відбуватися виключно на загальних підставах, у повній відповідності до правових засад, які полягають у наголошенні на дотриманні рівності громадян перед законом і судом. Саме подібні принципи здійснення кримінальних та адміністративно-правових проваджень щодо осіб, які тимчасово користуються недоторканністю, й слід вважати такими, що відповідають найвищим світовим стандартам 3-поміж країн правового та демократичного табору. 
Задля того, аби більш краще вивчити та дослідити різноманітні фактори впливу наявності недоторканності у певних державних осіб, а також оцінити та зважити позитивні та негативні наслідки застосування такої практики, варто провести якісний аналіз законодавчих систем розвинених та успішних зарубіжних держав у сфері регулювання правового становища голів таких держав, їх парламентаріїв та суддів. Висновки, що були сформульовані вітчизняними правознавцями наприкінці їх наукових досліджень іноземних державно-політичних систем, склалися у декілька умовиводів [2].

Перш за все потрібно підкреслити, що політичні особи країн Західного світу, зокрема, і законодавці, здійснюють свої повноваження на підставі так званого «вільного», або загальнонаціонального, депутатського мандата. У тих країнах Свропи, де застосовується практика проведення виборів здебільшого на пропорційній основі, депутати отримують свій мандат непрямим шляхом, а саме шляхом розподілення мандатів відповідно до кількості отриманих голосів виборців під час проведення виборів до законодавчого органу влади.

Також варто додати, що через здійснення парламентаріями своїх професійних обов'язків до них цілком логічно висуваються деякі вимоги морально-етичного характеру, наприклад, з приводу несумісності їхнього мандата з іншими, зокрема, комерційними видами діяльності. Окрім цього, серед розвинених країн із двопалатною законодавчою системою існує традиційна різниця між правовим становищем членів верхніх і нижніх палат парламенту. У даному випадку усе залежить від ролі та впливу конкретної палати на політичні та законотворчі процеси в країні. Уваги потребує також і питання щодо типу правової системи, що має місце у тій чи іншій країні, адже воно є ключовим при розгляді змісту і обсягу парламентської недоторканості депутатів.

Вченими підкреслюється, що у правових та демократичних країнах Заходу відбувається поступове зменшення діапазону та вагомості ролі політичної недоторканності у системі здійснення державної влади. Найбільш помітними такі процеси $є$ насамперед у країнах континентальної Свропи, де 6 поширеною романо-германська правова система. У таких державах ще донедавна існувала відносно сильна система захисту членів законодавчих органів влади, зокрема, і від кримінального переслідування.

Натомість, у Великій Британії, Австралії, Канаді та Сполучених Штатах Америки, тобто країнах англо-американського права, недоторканість політичних осіб, у тому числі від притягнення до кримінальної відповідальності, визнається доволі обмеженою, що обумовлено насамперед історичними традиціями цих країн, а також наявністю у цих державах сильної та незалежної судової системи.

Проте, при розгляді рівня політичної недоторканності та обсягу владних повноважень у голів виконавчої влади цих держав варто наголосити, що, наприклад, у СШША $€$ наявним дуже сильний та впливовий політичний інститут президентства, тобто у цій країні президентська посада є одним 3 ключових засад повсякденного існування та життєдіяльності цієї держави. Американський президент хоча і належить традиційно до однієї 3 двох політичних партій, але він є самостійною та дуже потужною фігурою у політичній системі Сполучених Штатів. Зокрема, він наділений владою одноособово приймати величезний обсяг рішень, що стосуються повсякденного існування та безпеки країни, адже він $є$ верховним головнокомандувачем збройних сил i, водночас, головою уряду, тому йому підзвітні усі федеральні виконавчі департаменти (міністерства) СШІА.

Звичайно, що в Америці, як у справжній розвиненій демократичній країні, де традиційно існувало верховенство права, завжди мали місце речі, які успішно стримували усі можливі негативні наслідки сильної президентської влади. До таких речей перш за все потрібно віднести систему стримувань і противаг, яка, у свою чергу, полягає в існуванні сильної законодавчої влади двопалатного Конгресу, який, до речі, ніким не може бути розпущений, а також сильної, незалежної та політично незаангажованої судової системи, що по праву є предметом гордості усіх американців [3]. 


\section{Теорія, історія держави і права, конституційне право}

А у країнах Европи, навпаки, здавна склався принцип відносної колегіальності виконавчої влади, при якому або голова уряду (особливо на контрасті з одноосібною виконавчою владою американського президента) є дуже сильно залежним від своєї політичної партії чи конкретно фракції у парламенті, а тому повинен ретельно корегувати та погоджувати свою діяльність з членами своєї політичної сили, (Об'єднане Королівство, Німеччина, Нідерланди, Італія та ін.), або ж взагалі посада одноосібного голови уряду є повністю відсутньою, а замість неї існує прописана у законодавстві колегіальна рада вищих осіб держави (Швейцарія).

Треба зауважити, що серед спільних рис, які існують між політичними системами СІІА та країн Европейського Союзу, є, наприклад, фактор доволі обмеженого імунітету представників законодавчої гілки державної влади, який, до речі, діє здебільшого лише під час здійснення законодавцями своїх професійних функцій, тобто виконання власних депутатських обов'язків. Окрім цього, наявною також є майже повна відсутність хоча 6 якогось імунітету від кримінальних переслідувань у суддів. Ця характерна риса системи північноамериканського та західноєвропейського судочинства майже усіма вітчизняними та зарубіжними правознавцями визнається такою, що є своєрідним взірцем для судових систем інших країн.

Aле все ж таки потрібно наголосити, що надзвичайно успішне та ефективне функціонування цих згаданих вище судових систем 6 можливим лише у країнах із розвиненим ліберально-демократичним державним устроєм, а також, що є не менш важливим, справжнім, а не фіктивним пануванням верховенства права над усіма сферами суспільно-політичного життя країни. На додаток до цього слід згадати ще декілька важливих чинників, що забезпечують високий рівень правосуддя та справедливості у згаданих країнах.

Окрім ефективного органу законодавчої влади та справедливої судової системи, надзвичайно впливовими суспільними факторами у західних країнах є засоби масової інформації, потужно розвинена гро- мадськість, яка активно контролюе усі дії та кроки представників державної влади, а також існування методів правомірного втручання громадян у політичні процеси та існування широких можливостей для цілком легального і миттевого корегування внутрішньо- і зовнішньополітичного руху держави. Усі наведені засоби ефективного контролю за діяльністю органів державної влади дозволяють розвиненим демократично-правовим державам обходитися без потреби у наділенні осіб із владними повноваженнями якимись привілеями, на кшталт недоторканості.

Доречно буде зауважити, що у зв'язку із нещодавно прийнятим Верховною Радою України Законом «Про внесення змін до статті 80 Конституції України (щодо недоторканності народних депутатів України)», який набере чинності 1 січня 2020 року [4], єдиною політичною особою, що має широкий ступінь недоторканості, залишиться лише Президент України. Адже відомо, що вітчизняні судді хоча і зберігають наразі певний рівень недоторканності, проте, вони не є політичними фігурами [5].

Отже, базуючись на нещодавніх змінах, що відбулися після проведення в Україні парламентських виборів 21 липня 2019 року, слід вказати на те, що незважаючи на довгоочікувану реалізацію волевиявлення громадян України, тобто ліквідацію імунітету від переслідувань, яким так часто полюбляли зловживати народні депутати, таке діяння потенційно може нести в собі і певні ризики, особливо у недостатньо сформованій правовій державі.

Мова йде про те, що при недостатньо ефективно діючій системі стримувань і противаг у державі, а також при високому рівні корупції та інших зловживань серед вищих осіб держави існують ризики залякування та подальшого використання у злочинних цілях тих політичних осіб, що не мають дієвих засобів самозахисту від подібних злочинних посягань (наприклад, депутатського імунітету).

\section{Висновки}

Підсумовуючи усі думки відомих експертів та науковців $з$ цього приводу, доцільно 
буде констатувати те, що незважаючи на можливі ризики для держави і суспільства, які можуть стати реальністю після нещодавньої ліквідації імунітету від юридичних переслідувань у народних депутатів України, рішення про відміну депутатської недоторканості було абсолютно виваженим. Адже на прикладі нашої ж сучасної історії ми могли спостерігати, що при деяких минулих президентах навіть та ж недоторканність депутатів аж ніяк не була на заваді узурпації влади, негативні наслідки якої українському народові вже не раз доводилося ліквідовувати лише за допомогою масових акцій протесту та Революції гідності.

Найбільш надійним та єдиним правильним способом позитивного для українського народу та громадськості вирішення цієї проблеми є комплексний підхід у реформуванні вітчизняних державно-владних інститутів та переведенні їх на один рівень з високими нормами та стандартами функціонування таких установ у розвинених країнах Північної Америки та Західної Европи.

Серед конкретних кроків, що мають бути зроблені представниками вищого державного керівництва країни, обов'язково повинні бути запровадження найбільш ефективних методів знищення корупційних схем, 3 огляду на досвід найбільш успішних в цьому сенсі країн, якісний розвиток вітчизняної освіти та науки, термінове покращення рівня життя звичайних громадян та робота над поверненням тимчасово окупованих українських територій.

\section{Мітература}

1. Офіційний портал Верховної Ради України. URL: https://rada.gov.ua/ (дата звернення 28.09.2019).

SUMMARY
The issues of legalsupport for the inviolability of
the President and the People's Deputies of Ukraine
are considered. By analyzing scientific views, the
author defines the concepts of "inviolability" and
"legal support" (in relation to the legal status of
special subjects). The characteristic features of the
activities of such entities and their legal status as
prerequisites for their inviolability are identified.
Suggestions were made regarding the improvement
of the Institute of the Presidential and People's
Deputies of Ukraine. Amendments to the national
legislation are proposed to increase the effectiveness
of the activity of the people's deputies and to
improve the motivationally-encouraged forms of
their professional activity.
Keywords: inviolability, legal security, legal
equality, specialstatus, state power, legal regulation,
legislation, branch of power, reforms.

2. Офіційне інтернет-представництво Президента України. URL: https:// www.president.gov.ua/ (дата звернення 28.09.2019).

3. Система державного управління Сполучених Штатів Америки: досвід для України / за заг. ред. Ю. В. Ковбасюка, С. В. Загороднюка. Київ: НАДУ, 2011. 52 с.

4. Про внесення змін до статті 80 Конституції України (щодо недоторканності народних депутатів України): Закон України від 03.09.2019. URL: https://zakon.rada. gov.ua/laws/show/27-20 (дата звернення 28.09.2019).

5. Про судоустрій і статус суддів: Закон України від 03.06.2016. URL: https://zakon. rada.gov.ua/laws/show/1402-19 (дата звернення 28.09.2019). 